\title{
Effect of soil and water characteristics on yield and properties of 'Spunta' potatoes
}

\author{
Saad A. Al-Hamed ${ }^{1}$, Mohammed F. Wahby ${ }^{1}$, Abdulwahed M. Aboukarima ${ }^{2}$,
} and Mohamed S. El Marazky ${ }^{1,2 *}$

\section{ABSTRACT}

Soil texture and its characteristics besides water characteristics can play an eminent role in potato (Solanum tuberosum L.) production. Therefore, a soil and water quality index (SWQI, \%) was derived to investigate the effect of combination of soil and water characteristics (sodium adsorption ratio for water and soil, electric conductivity of water and soil, $\mathrm{pH}$ for water and soil, organic matter in the soil, and soil texture index) on yield and properties of 'Spunta' potatoes produced under center pivot irrigation system. This index was formed studying separately the effect of irrigation water quality and soil texture on yield, water use efficiency, tuber modulus of elasticity, and tuber shape index of 'Spunta' potatoes. Field results demonstrated that the lowest potato yield was approximately $34.12 \mathrm{tha}^{-1}$ at SWQI 79.63\%, and the highest potato yield was $37.79 \mathrm{t} \mathrm{ha}^{-1}$ at SWQI of $30.93 \%$. The lowest water use efficiency was approximately $6.09 \mathrm{~kg} \mathrm{~m}^{-3}$ at SWQI $30.93 \%$, and the highest water use efficiency was $6.83 \mathrm{~kg} \mathrm{~m}^{-3}$ at SWQI 79.63\%. The lowest tuber modulus of elasticity was approximately 3.98 $\mathrm{N} \mathrm{mm}{ }^{-1}$ at SWQI $21.7 \%$, and the highest tuber modulus of elasticity was $4.74 \mathrm{~N} \mathrm{~mm}^{-1}$ at SWQI 79.63\%. Finally, the tuber shape index was approximately $342 \%$ at SWQI $79.63 \%, 418 \%$ at SWQI $21.72 \%$, and $403 \%$ at SWQI $30.93 \%$, which belongs to long and very long shapes. The soil and water quality index could be a useful tool to get relationships among water and soil characteristics, yield, and other properties of the potato crop.

Key words: Irrigation, potatoes, sodium adsorption ratio, soil and water quality index, Solanum tuberosum.

${ }^{1}$ King Saud University, College of Food and Agriculture Sciences, P.O. Box 2460, Riyadh 11451, Saudi Arabia.

${ }^{2}$ Agricultural Engineering Research Institute (AEnRI), Agricultural Research Centre, P.O. Box 256, Giza, Egypt.

*Corresponding author (elmarazky58@gmail.com).

Received: 7 March 2017.

Accepted: 18 June 2017.

doi:10.4067/S0718-58392017000300250

\section{INTRODUCTION}

Agriculture is an important economic sector in Saudi Arabia, its percentage share of gross national product was $2.3 \%$ in year 2015 (The World Factbook, 2016). Potato (Solanum tuberosum L.) is one of the most important field crops in Saudi Arabia because of its role in providing food and proteins (Hadi, 2012). Average yields vary between 21 and $40 \mathrm{t} \mathrm{ha}^{-1}$ (Al-Gaadi et al., 2016). Increased mechanization was one of the most influential factors in the ability to expand potato production and minimize the production cost, thus increasing the net income for potato producers (Al-Dosary, 2016). However, potato production is established under different patterns of mechanization, irrigation water quality, and soil type. Additionally, the most important factors affecting potato production are potato variety, irrigation, and fertilizer (Abdelaziz et al., 2010).

Center pivots are the most commonly used irrigation system for potato production (King and Stark, 2005). Center pivot irrigation is the most efficient means of providing supplemental water to potato crops. Timing and placement of the water are more accurately controlled compared to other irrigation systems. Center pivots can be effectively used during all stages of production. In addition, center pivots can be used during harvest to increase soil moisture and improve harvesting conditions (Arnold et al., 2009). Uniformity of a system is a measure of its ability to apply the same depth of water to every unit area. Distribution uniformity is useful as an indicator of the magnitude of distribution problems. It is calculated by dividing the weighted average of the lowest $25 \%$ of the catch cans by the weighted average of the entire catch cans. A distribution uniformity of $85 \%$ or greater is considered excellent, $80 \%$ is considered very good, $75 \%$ is considered good, $70 \%$ is considered fair, and $65 \%$ or less is considered poor and unacceptable (Merriam and Keller, 1973).

Irrigation water quality refers to the suitability of its use for irrigation purposes (Tanji, 1990; Shamsad and Islam, 2005). High quality crops can be produced only by using high-quality irrigation water, while keeping other inputs optimal. Characteristics of irrigation water that define its quality vary with the source of the water (Islam and Shamsad, 2009). The parameters that determine irrigation water quality are divided into three categories: chemical, physical, and biological. The chemical characteristics of irrigation water refer to the content of salts in the water and parameters derived from the composition of these salts; parameters such as electrical conductivity (EC), total dissolved solids, and sodium adsorption ratio (SAR) (Sela, 2016). 
Ground water is a major source for irrigation in arid and semi-arid regions, and the widely-accepted standard for irrigation water is the United States Salinity Laboratory (US Department of Agriculture, Agricultural Research Service, Riverside, California, USA) classification system, which is based on SAR and EC (Priya, 2013). SAR is a representation of sodium hazard. The value of SAR is used to evaluate the suitability of water for irrigation (Khattak et al., 2012); it is the estimation of the degree to which $\mathrm{Na}$ will be adsorbed by the soil. A high SAR value means that $\mathrm{Na}$ enhances the dispersion of colloids or clays when it comes in contact with the soil and may replace $\mathrm{Ca}$ and $\mathrm{Mg}$ ions in the soil, resulting in damage to the soil structure and reduction in its capacity to conduct water and air (Lloyd and Heathcote, 1985). Increasing salinity of irrigation water significantly reduced total and average tuber yields for potato 'Cara', 'Alpha', 'Spunta', and 'King Edward' (El-Khatib et al., 2004). In addition, Levy and Veilleux (2007) described the effects of salinity on the growth of potato plant and on tuber yield and traits. There were nonsignificant differences in plant growth or tuber yields from the three seed sources in most varieties, indicating the possibility of using saline water for the production of potato seed tubers (Levy and Taib, 2013). SAR is a measure of the sodicity of soil, as determined from analysis of water extracted from the soil. The formula for calculating SAR is (Suarez et al., 2008):

$$
S A R=\frac{\mathrm{Na}^{+}}{\sqrt{\frac{1}{2}\left(\mathrm{Ca}^{++}+M g^{++}\right)}}
$$

where $\mathrm{Na}^{+}, \mathrm{Ca}^{++}$, and $\mathrm{Mg}^{++}$represent concentrations expressed as meq $\mathrm{L}^{-1}$.

Karam et al. (1998) studied effects of saline irrigation water on leaf area, dry matter (DM), and potato yield. Values of EC for saline waters were 2.3, 2.7, and 3.6 dS

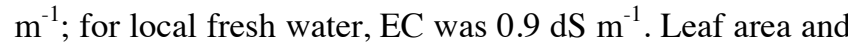
DM showed that salt stress reduced the leaf surface and consequently the biomass. Yield was sensitive to salinity, but water use efficiency was not affected.

Van Hoorn et al. (2002) grew potatoes in tanks filled with loam and clay and irrigated with water of three different levels of salinity; water efficiency of potatoes was not affected by soil and water salinity. El Mokh et al. (2015) showed that potato tuber yield varied widely under different amounts of water that was applied with different EC through drip irrigation at different levels. A higher salinity associated with deficit irrigation caused significant reductions in tuber yield and its components. Initial soil salinity values determined at planting were 4.9 and 3.7 $\mathrm{dS} \mathrm{m}{ }^{-1}$ in the first and second year, respectively.

Field preparation for potato planting is very important, and, therefore, using suitable water characteristics can play an eminent role. Thus, the objective of this research was to develop an index called soil and water quality index (SWQI). This index was formed studying the effect of irrigation water quality and soil texture separately on yield, water use efficiency, tuber modulus of elasticity, and tuber shape index of 'Spunta' potatoes. The irrigation water characteristics were evaluated by sodium adsorption ratio, electric conductivity and $\mathrm{pH}$. Moreover, soil characteristics were evaluated by SAR, EC, organic matter percentage, soil texture index and $\mathrm{pH}$.

\section{MATERIALS AND METHODS}

\section{Experimental site and procedures}

Effects of irrigation water quality and soil texture on potato yield, water use efficiency, modulus of elasticity, and shape index of 'Spunta' potatoes were studied separately. Experiments were conducted at a private farm in AlKharj Governorate (248'54" N, 47¹8'18" E), Saudi Arabia. Soil samples were analyzed in the laboratory of the Soil Department, College of Food and Agriculture Sciences, King Saud University, Riyadh. Irrigation water samples were collected from the nozzles of three similar companies' center pivots and analyzed in Inspection, Diagnosis and Analysis Lab Company (IDAC), Medical Biology Analytical Laboratories, Riyadh, Al Kharj Road, Saudi Arabia. Soil parameters such as sand, silt, and clay percentages, organic matter percentage, $\mathrm{pH}$, and soil EC were obtained from laboratory analysis. Table 1 illustrates soil characteristics and Table 2 illustrates water characteristics at the experimental location.

The experimental setup consisted of a completely randomized block design with three replicates. The soil was prepared by a moldboard plow operated at a tractor forward speed of $5.4 \mathrm{~km} \mathrm{~h}^{-1}$. This speed was achieved by selecting an appropriate gear. The adjusted tillage depth was $15 \mathrm{~cm}$. The size of the plots was $12 \mathrm{~m} \times 40 \mathrm{~m}$ and were separated by $2 \mathrm{~m}$. A $78 \mathrm{~kW}$ tractor pulled the tillage implement during tillage experiments. The moldboard plow

Table 1. Characteristics of the soil at the experimental site.

\begin{tabular}{lccc}
\hline Parameter & Soil 1 & Soil 2 & Soil 3 \\
\hline Sand, \% & 82.90 & 86.92 & 83.89 \\
Silt, \% & 13.08 & 6.04 & 13.45 \\
Clay, \% & 4.02 & 7.04 & 2.66 \\
Soil texture, & Loamy sand & Loamy sand & Loamy sand \\
Organic matter, \% & 0.98 & 0.07 & 0.16 \\
pH & 8.50 & 8.80 & 7.32 \\
Electrical conductivity, dS m & -1 \\
Sodium adsorption ratio & 4.60 & 2.90 & 0.83 \\
$\mathrm{Na}^{+}, \mathrm{mg} \mathrm{kg}^{-1}$ & 1.08 & 0.21 & 0.36 \\
$\mathrm{~K}^{+}, \mathrm{mg} \mathrm{kg}^{-1}$ & 48.66 & 17.41 & 78.0 \\
$\mathrm{Ca}^{++}, \mathrm{mg} \mathrm{kg}^{-1}$ & 4.91 & 2.78 & 5.43 \\
$\mathrm{Mg}^{++}, \mathrm{mg} \mathrm{kg}^{-1}$ & 140.59 & 485.69 & 99.03 \\
\hline
\end{tabular}

Table 2. Characteristics of irrigation water at the experimental site.

\begin{tabular}{|c|c|c|c|}
\hline Parameter & Water 1 & Water 2 & Water 3 \\
\hline $\mathrm{Na}^{+}, \mathrm{mg} \mathrm{L}^{-1}$ & 372.07 & 237.27 & 58.10 \\
\hline $\mathrm{Ca}^{++}, \mathrm{mg} \mathrm{L}^{-1}$ & 404.75 & 309.40 & 75.45 \\
\hline $\mathrm{Mg}^{++}, \mathrm{mg} \mathrm{L}^{-1}$ & 109.78 & 86.86 & 11.85 \\
\hline TDS, $\mathrm{mg} \mathrm{L}^{-1}$ & 3204.79 & 2317.68 & 660.00 \\
\hline $\mathrm{pH}$ & 7.57 & 7.55 & 7.81 \\
\hline Electrical conductivity, $\mathrm{dS} \mathrm{m}^{-1}$ & 4.81 & 3.48 & 0.99 \\
\hline Sodium adsorption ratio & 4.23 & 3.07 & 1.64 \\
\hline
\end{tabular}

TDS: Total dissolved solids. 
(mounted type) had two bottoms and a working width of $80 \mathrm{~cm}$. The tillage implement passed one time over the soil surface. 'Spunta' potato (country of origin The Netherlands) was utilized, seed size was $35 / 55 \mathrm{~mm}$ and was treated with imazalil $((R S)-1-(\beta$-allyloxy-2,4-dichlorophenethyl) imidazole). An automatic cup-belt potato planter (Model: Tekyataganli, Tekyataganli Agricultural Machine Industry Co Inc., Selcuklu, Konya, Turkey) was used in planting. The recommended fertilization rate by Saudi Agricultural Ministry was applied. Planting was completed in autumn on 2 October 2014 and harvested on 14 February 2015.

Effects of irrigation water quality and soil texture on potato yield, water use efficiency, modulus of elasticity, and shape index of 'Spunta' potatoes were studied separately; thus, water and soil characteristics are combined in one index called soil and water quality index (SWQI, \%), which is calculated as:

$$
S W Q I=\frac{S A R_{W}}{S A R_{S}} \times \frac{E C_{W}}{E C_{S}} \times \frac{p H_{W}}{p H_{S}} \times \frac{O M}{S T I} \times 100
$$

where $S A R_{W}$ is sodium adsorption ratio for water; $S A R_{S}$ is sodium adsorption ratio for soil; $E C_{W}$ is water $\mathrm{EC}$ $\left(\mathrm{dS} \mathrm{m} \mathrm{m}^{-1}\right) ; E C_{S}$ is soil EC $\left(\mathrm{dS} \mathrm{m} \mathrm{m}^{-1}\right) ; p H_{W}$ and $p H_{S}$ are $\mathrm{pH}$ values for water and soil, respectively; $O M$ is organic matter in the soil (decimal); and STI is soil texture index, which was developed by Oskoui and Harvey (1992), and selected because it produces unique numbers for every combination of sand, silt, and clay content. STI represents soil components and is calculated as:

$$
S T I=\frac{\log \left(S_{i}^{c c_{a}}\right)}{100}
$$

where $S_{i}$ and $C C_{a}$ are the percent of silt and clay fractions in the soil, respectively. However, the sand fraction is represented implicitly since the sum of sand, silt, and clay fractions is always constant. Oskoui and Harvey (1992) showed that the STI reflects the effects of all three soil fractions.

\section{Yield and irrigation water use efficiency}

To determine potato yield, the five middle plants in each plot were harvested by hand and weighed. Next, tubers were separated from the plants, weighed, and tuber yield was recorded in $\mathrm{t} \mathrm{ha}^{-1}$. Water use efficiency (WUE) is expressed as the ratio of potato yield to the amount of water supply from planting to harvest. It is calculated as (Tanner and Sinclair, 1983):

$$
\text { WUE }\left(\mathrm{kg} \mathrm{m}^{-3}\right)=\frac{\text { Yield }\left(\mathrm{kg} \mathrm{ha}^{-1}\right)}{\text { Amount of water }\left(\mathrm{m}^{-3} \mathrm{ha}^{-1}\right)}
$$

\section{Field evaluation of center pivot sprinkler irrigation systems}

The distribution uniformity (DU) in the low quarter of the center pivot irrigation system was determined for three pivots. The formula for determining DU was (ASABE, 2007):

$$
\mathrm{DU}=\frac{d_{w}}{D_{w}} \times 100
$$

where $d_{w}$ is the average of caught low quarter depth (mm) and $D_{w}$ is the average of total caught applied depth. The field evaluations were conducted adopting the methodology of Merriam and Keller (1978) and ASABE (2007). The catch can spacing of $5 \mathrm{~m}$ was chosen, with the first can at $11.6 \mathrm{~m}$ from the pivot point (Figure 1). Catch cans of $16 \mathrm{~cm}$ inside diameter and $15 \mathrm{~cm}$ height were used. The volume caught in each can was then converted to a depth in $\mathrm{mm}$ and plotted against the distance of each can position from the pivot point to give a visual display of the water caught in cans along the lateral line. The operating speed of the systems was a constant $50 \%$ of rated speed for all tested pivots. There was no end-gun sprinkler installed on any system tested. All tests were carried out under normal field conditions in the early morning to minimize evaporation losses. Graduated cylinders measured the water collected in the catch cans.

The average applied water depth was approximately 5.38 $\mathrm{mm}$ in Soil 3, $10.74 \mathrm{~mm}$ in Soil 1, and $8.08 \mathrm{~mm}$ in Soil 2. The number of irrigations was approximately 60; therefore, the total applied water during the growing season was 3228 $\mathrm{m}^{3} \mathrm{ha}^{-1}$ in Soil 3, $6444 \mathrm{~m}^{3} \mathrm{ha}^{-1}$ in Soil 1, and $4848 \mathrm{~m}^{3} \mathrm{ha}^{-1}$ in Soil 2. Distribution uniformity of the studied center pivots (Fermond-Valley type) was $65.87 \%, 72.04 \%$ and $67.07 \%$ for pivots in Soil 1, Soil 2, and Soil 3, respectively. It is evident that all pivots were old and needed maintenance owing to lower values of distribution uniformity.

\section{Tuber shape index determination}

Three mutually perpendicular axes of a potato were measured with a digital slide caliper (Figure 2), after the potato was laid on a flat surface and had reached its natural resting position. The longest intercept $\mathrm{L}$ (represented tuber length), D (the longest intercept normal to L) represented tuber width, and T (the longest intercept normal to D, L) represented the thickness of the tuber (Tabatabaeefar, 2002). Five randomized samples of potato tubers were carefully obtained during harvesting (fresh tubers). All measurements were conducted at the laboratory of Food Engineering at the Department of Agricultural Engineering, College of

Figure 1. Evaluation of water depth for center pivot.

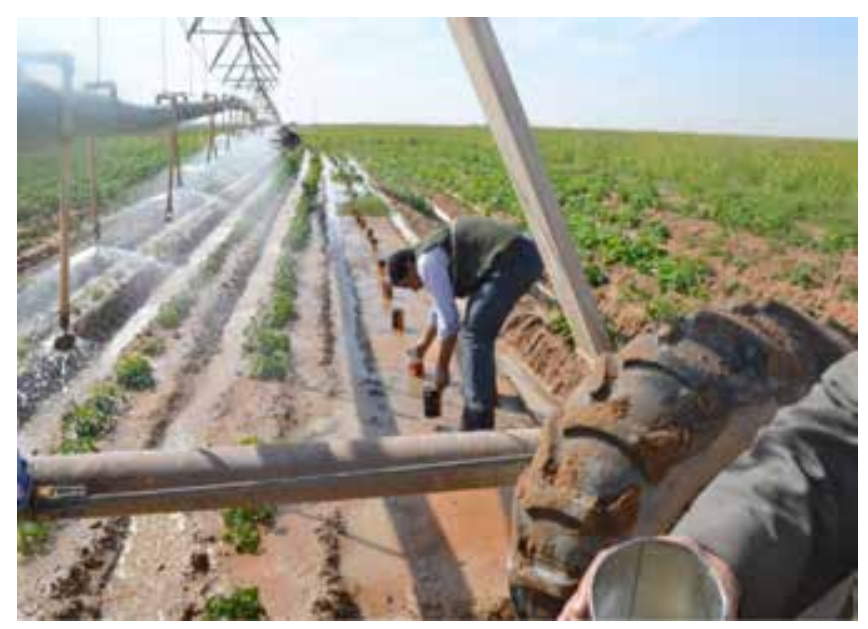


Figure 2. Three mutually perpendicular axes of potatoes.

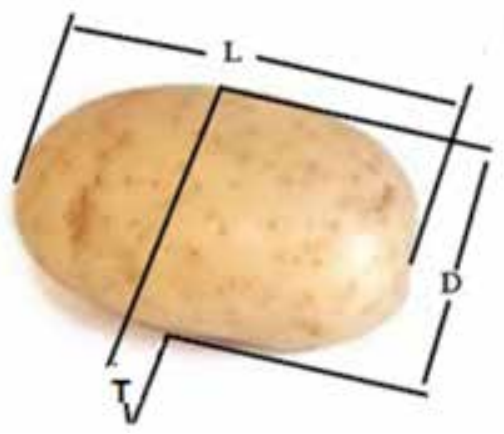

Agriculture and Food Sciences, King Saud University. The shape index of potato tubers was calculated according to Singh et al. (2004) as:

$$
P S I=\frac{L^{2}}{D T} \times 100
$$

where $P S I$ is the shape index, and $L, D$, and $T$ are the length, width, and thickness of potato tubers ( $\mathrm{mm})$, respectively. The obtained shape index was compared with the recommended limits and classified into different classes (PSI from 100 to 160 as round, 160 to 240 as oval, 240 to 340 as long, and higher than 340 as very long).

\section{Tuber modulus of elasticity}

Force-deformation curves under compression tests of potatoes were investigated. A texture analyzer (TA-HDi, Model HD3128, Stable Micro Systems, Surrey, UK) was used to perform tests. The texture analyzer was interfaced with a PC and Texture Expert Exceed software (version 2.05), which allowed data to be acquired and analyzed. All experiments were conducted at room temperature $\left(23^{\circ} \mathrm{C}\right)$. Before carrying out the tests, the load cell and probe distance of the instrument were calibrated following the methods and tools provided by the company. For the compression tests, the experiments were carried out by using individual potatoes oriented parallel to the compression surfaces at a crosshead speed of $1.5 \mathrm{~mm} \mathrm{~s}^{-1}$ using an aluminum plunger $(\mathrm{P} / 75)$ of $75 \mathrm{~mm}$ diameter (Figure 3a). Tuber modulus of elasticity $\left(\mathrm{N} \mathrm{mm}^{-1}\right)$, extracted from force-deformation curves under compression tests (Figure 4), was defined as the slope of the straight line through point a and point P1 on Figure 4.

\section{RESULTS AND DISCUSSION}

\section{Soil and water analysis}

All soils have loamy sand texture, and soil EC was variable as its value was $4.6 \mathrm{dS} \mathrm{m}^{-1}$ in Soil $1,8.8 \mathrm{dS} \mathrm{m}^{-1}$ in Soil 2 and $7.32 \mathrm{dS} \mathrm{m}^{-1}$ in Soil 3 and SAR was 1.08, 0.21, and 0.36 for Soil 1, Soil 2, and Soil 3, respectively (Table 1). From these data, it is clear that all soils have EC above the critical value of soil EC associated with maximum potato tuber yield; to avoid potato tuber yield reduction, this value was $1.60 \mathrm{dS}$ $\mathrm{m}^{-1}$, as reported in Roberto et al. (1999). Moreover, soft texture components (sand, silt, clay) had a stronger impact
Figure 3. Compression test of potato tubers.

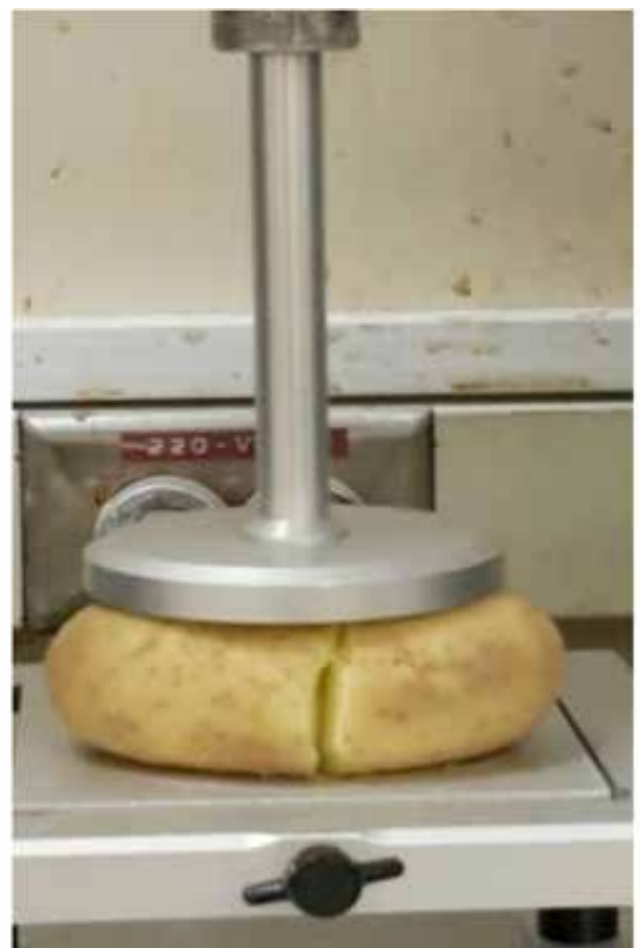

Figure 4. Force-deformation of food materials (ASAE, 2002).

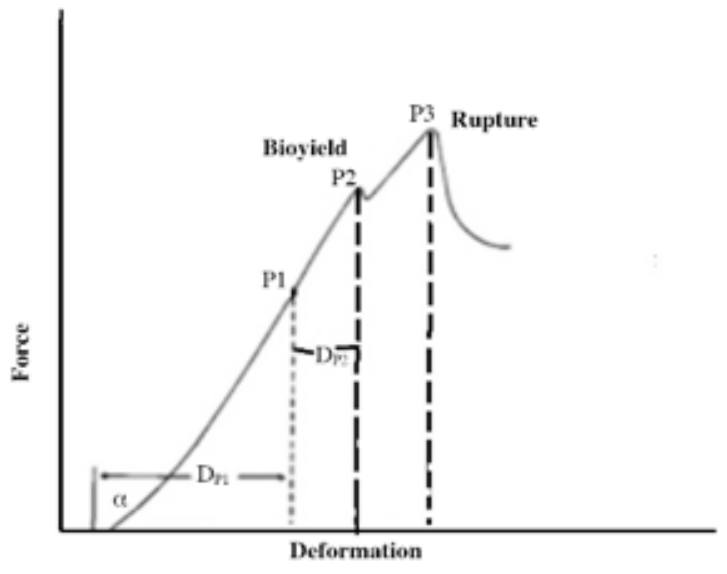

on potato yield than soil chemical properties (Redtflla et al., 2002). Additionally, a worthy crop of potatoes can be grown in loam soil at daily irrigation rates (Miller and Martin, 1983). Furthermore, high levels of salt can potentially affect yield and potato tuber quality (Moore et al., 2011).

Water EC was $4.6 \mathrm{dS} \mathrm{m}^{-1}$ for Water $1,4.81 \mathrm{dS} \mathrm{m}^{-1}$ for Water 2, and $0.991 \mathrm{dS} \mathrm{m}^{-1}$ for Water 3; and SAR was 4.23, 3.07, and 1.64, for Water 1, Water 2, and Water 3, respectively (Table 2). Water quality with EC equal to 0.625 $\mathrm{dS} \mathrm{m} \mathrm{m}^{-1}$ and SAR equal to 0.61 had no restriction on use for potato cultivation (Yavuz et al., 2012). Yield reductions in the potato crop were $0 \%, 10 \%, 25 \%$, and $50 \%$ when EC of irrigation water was 1.1, 1.7, 2.5, and $3.9 \mathrm{dS} \mathrm{m}^{-1}$, respectively (Ayers and Westcott, 1989). Tuber weight, tuber number, and total yield were significantly decreased 
when the saline level of water increased up to an EC value of $1.5 \mathrm{dS} \mathrm{m}^{-1}$ (Barakat, 1996; Abd El-Aal, 2001). Based on values of SAR, a low Na hazard is evident in the studied location. From the water and soil characteristics shown in Tables 1 and 2, SWQI had three values: $21.72 \%, 30.93 \%$ and $79.63 \%$.

Effect of SWQI on yield, water use efficiency, modulus of elasticity, and shape index of 'Spunta' potato

Crop models are powerful tools to study the effects of variable inputs on yield and other components. In the same way, building a methodology able to predict the yields on the regional scale would be of major interest (Brisson et al., 2003; 2009). The combination factors that affect potato yield are water and soil characteristics, if recommended fertilizers and water amount are applied. These factors are also likely to be responsible for yield variability. Moreover, they can have cumulative impacts on potato yields and they can interact with one another. Therefore, in this study, a SWQI that combined soil and water characteristics was utilized to study behavior of yield, water use efficiency, modulus of elasticity, and shape index of 'Spunta potatoes'.

Figures 5-8 depict the relationship between SWQI and potato yield, water use efficiency, modulus of elasticity, and shape index of 'Spunta' potatoes, respectively. It is clear from Figure 5 that the relationship between SWQI and potato yield was quadratic with high correlation, increasing SWQI results in decreasing yield; and this relation may be due to the effect of combination of SAR and EC of water. However, the interaction between potato varieties and different saline water levels had a significant effect on tuber number per plant (Samy, 2015). In addition, findings by Abdullah and Ahmed (1990) indicated that tuber number per plant increased with low salinity concentration and decreased with increasing salinity concentration. Moreover, potato tuber yield varied widely under different amounts of water, applied with different EC of water through drip irrigation at different levels (El Mokh et al., 2015). In this study, the lowest yield was $34.12 \mathrm{t} \mathrm{ha}^{-1}$ at a SWQI 79.63\% and the highest yield was $37.79 \mathrm{t} \mathrm{ha}^{-1}$ at a SWQI $30.93 \%$. The existing model on the figure could be useful for yield prediction.

Figure 5. The relationship between soil and water quality index and potato yield.

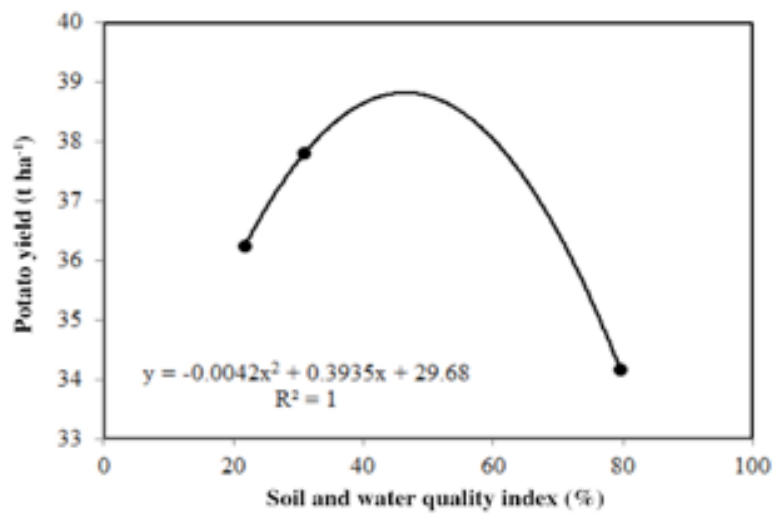

Figure 6. The relationship between soil and water quality index and water use efficiency.

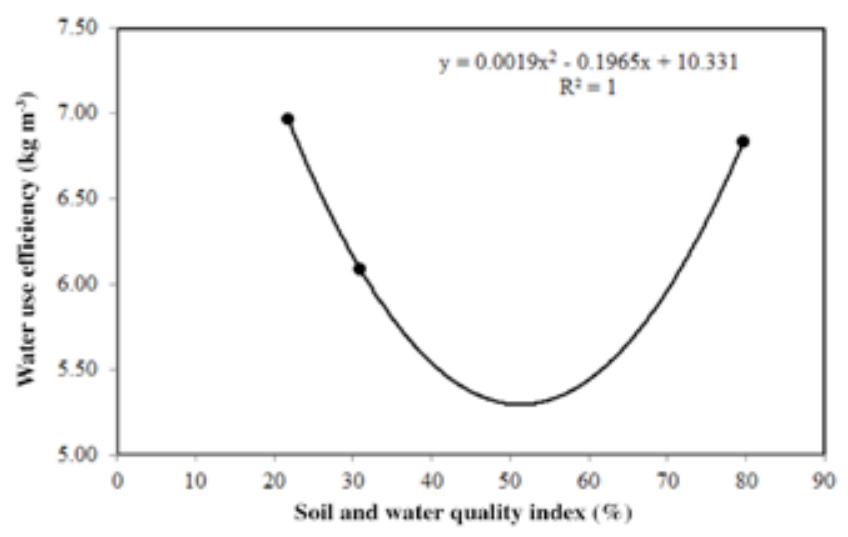

The water use efficiency, expressed as the ratio of potato yield to water supply from planting to harvest, varied typically from 9 to $11 \mathrm{~kg} \mathrm{~m}^{-3}$ (Nagaz et al., 2012). In this study, the relationship between SWQI and water use efficiency was quadratic with high correlation, and increasing SWQI results in increasing water use efficiency as illustrated in Figure 6 and this finding was due to the reduction in the potato yield. The lowest water use efficiency was approximately $6.09 \mathrm{~kg} \mathrm{~m}^{-3}$ at a SWQI of $30.93 \%$ and the highest water use efficiency was 6.83 $\mathrm{kg} \mathrm{m}^{-3}$ at a SWQI of $79.63 \%$.

After harvesting, a laboratory experiments were conducted to examine the mechanical properties of potatoes under quasi-static compression loading conditions. Five tests were conducted. The relationship between SWQI and tuber modulus of elasticity was linear with a coefficient of determination $\left(\mathrm{R}^{2}\right)$ of 0.8029 as illustrated in Figure 7. Increasing SWQI results in increasing tuber modulus of elasticity (Figure 7). The lowest tuber modulus of elasticity was approximately $3.98 \mathrm{~N} \mathrm{~mm}^{-1}$ at a SWQI of $21.7 \%$, and the highest tuber modulus of elasticity was $4.74 \mathrm{~N} \mathrm{~mm}^{-1}$ at a SWQI of $79.63 \%$.

The relationship between SWQI and tuber shape index was linear with a coefficient of determination $\left(\mathrm{R}^{2}\right)$ of 0.9985 and increasing SWQI results in decreasing shape index (Figure 8). The tuber shape index was approximately

Figure 7. The relationship between soil and water quality index and tuber modulus of elasticity.

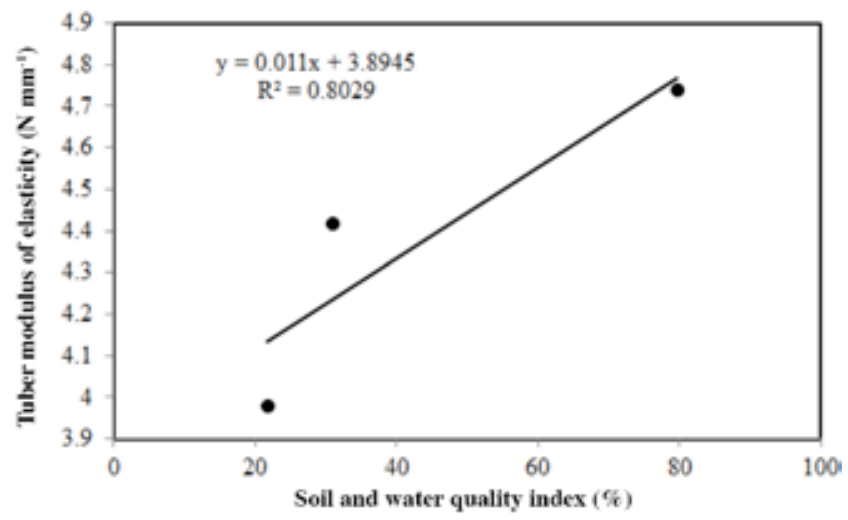


$342 \%$ at a SWQI $79.63 \%, 418 \%$ at a SWQI $21.72 \%$, and $403 \%$ at a SWQI $30.93 \%$, which belongs to long and very long shapes according to Singh et al. (2004) (Figure 8). However, Suliman et al. (1999) concluded that the shape of the 'Spunta' potato was long.

Figure 8. The relationship between soil and water quality index and tuber shape index.

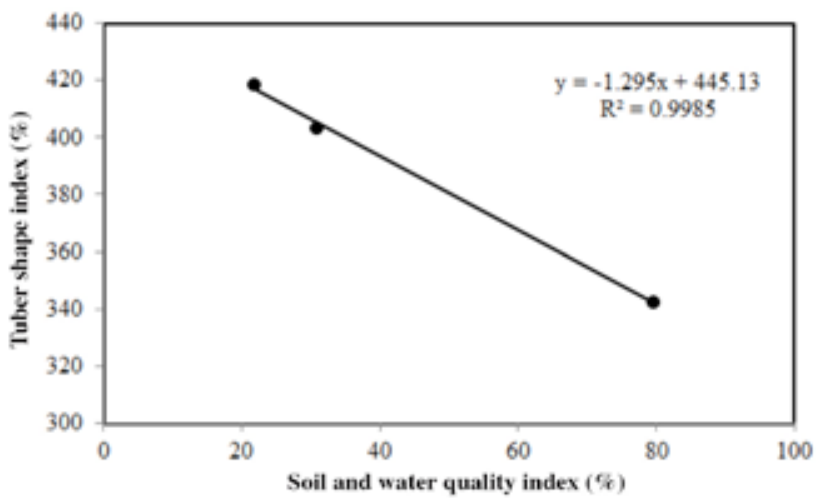

\section{CONCLUSIONS}

The combination of characteristics of soil and water, including sodium adsorption ratio, electric conductivity, $\mathrm{pH}$ for water and soil, organic matter and soil texture index on yield and properties of 'Spunta' potatoes produced under center pivot irrigation system through development of a water quality index (SWQI) was in the range of $21.72 \%$ to $79.63 \%$, where the relationship between SWQI and potato yield was quadratic with high correlation, and increasing SWQI results in decreasing yield. Increasing SWQI results in increasing tuber modulus of elasticity in a linear shape. Additionally, increasing SWQI results in decreasing shape index, an increasing SWQI results in increasing water use efficiency. Furthermore, it could be concluded that potato plants can be grown under saline water stress up to $4.6 \mathrm{dS} \mathrm{m}^{-1}$ in a loamy sand soil.

\section{ACKNOWLEDGEMENT}

With sincere respect and gratitude, we would like to express deep thanks to Deanship of Scientific Research, King Saud University and Agriculture Research Center, College of Food and Agriculture Sciences for the financial support, sponsoring and encouragement.

\section{LITERATURE CITED}

Abd El-Aal, A.M. 2001. Effect of irrigation with saline water on potato plants. MSc Thesis. 79 p. Cairo University, Faculty of Agriculture, Giza, Egypt.

Abdelaziz, H.H, Emam, A.A., and Taha, E.E. 2010. Economics of potato production in the northern part of Khartoum state. Journal of Science and Technology 11:30-33.

Abdullah, Z., and Ahmed, R. 1990. Effect of pre and post kinetin treatments on salt tolerance of different potato cultivars growing on saline soils. Journal of Agronomy and Crop Science 165:94-102.
Al-Dosary, N.M. 2016. Potato harvester performance on tubers damage at the eastern of Saudi Arabia. CIGR Journal 18:32-42.

Al-Gaadi, Kh.A., Hassaballa, A.A., Tola, E., Kayad, A.G., Madugundu, R., Alblewi, B., et al. 2016. Prediction of potato crop yield using precision agriculture techniques. PLoS ONE 11(9):e0162219. doi:10.1371/journal.pone.0162219.

Arnold, T.F., Smith, T.P., and Villordon, A. 2009. Improving sweet potato production efficiency: Optimizing soil moisture and irrigation management. Louisiana State University Agricultural Center, Baton Rouge, Louisiana, USA. Available at http:// www.lsuagcenter.com/portals/communications/publications/ agmag/archive/2013/summer/improvingsweetpotatoproduction (accessed date 12/6/2017).

ASABE. 2007. ASABE Standard S436.1. Test procedure for determining the uniformity of water distribution of center pivot and lateral move irrigation machines equipped with spray or sprinkler nozzles. American Society of Agricultural and Biological Engineers, St. Joseph, Michigan, USA.

ASAE standard. 2002. Compression test of food materials of convex shape. 8 p. American Society of Agricultural Engineers (ASAE), St. Joseph, Michigan, USA.

Ayers, R.S., and Westcott, D.W. 1989. Water quality for agriculture. FAO Irrigation and Drainage Paper 29. Rev. 1. 174 p.

Barakat, M.A. 1996. Effect of irrigation with saline water on growth, yield and chemical constituents of potato under calcareous soil conditions. Alexandria Journal of Agricultural Research 41:389-397.

Brisson, N., Gary, C., Justes, E., Roche, R., Mary, B., Ripoche, D., et al. 2003. An overview of the crop model STICS. European Journal of Agronomy 18:309-332.

Brisson, N., Launay, M., Mary, B., and Beaudoin, N. 2009. Conceptual basis, formalisations and parameterization of the STICS crop model. Editions Quae. Collection Update Sciences and Technologies.

El Mokh, F., Nagaz, K., Masmoudi, M.M., and Mechlia, N.B. 2015. Yield and water productivity of drip-irrigated potato under different nitrogen levels and irrigation regime with saline water in arid Tunisia. American Journal of Plant Sciences 6:501-510.

El-Khatib, H.A., El Khatib, E.A., KhalafAllah, A.M., and El Sharkawy, A.M. 2004. Yield response of salt stressed potato to potassium fertilization: A preliminary mathematical model. Journal of Plant Nutrition 27:111-122.

Hadi, M.R.H.S. 2012. Energy efficiency of potato crop in major production regions of Iran. International Journal of Agriculture and Crop Sciences 2:51-53.

Islam, M.S., and Shamsad, S.Z.K.M. 2009. Assessment of irrigation water quality of Bogra district in Bangladesh. Bangladesh Journal of Agricultural Research 34:597-608.

Karam, F., Katerji, N., Mastrorilli, M., van Hoorn, J.W., and Hamdy, A. 1998. Effects of irrigation water salinity and soil texture on potatoes growth and production. Acta Horticulturae 458:89-94.

Khattak, M.A., Ahmed, N., Qazi, M.A., Izhar, A., Ilyas, S., Chaudhary, M.N., et al. 2012. Evaluation of ground water quality for irrigation and drinking purposes of the areas adjacent to Hudiara industrial drain, Lahore, Pakistan. Pakistan Journal of Agricultural Sciences 49:549-556.

King, B.A., and Stark, J.C. 2005. Site-specific water and nutrient management in potato. Vol. 6. p. 54-59. Western Nutrient Management Conference, Salt Lake City. 3-4 March.

Levy, D., and Taib, G.C.C. 2013. Differential response of potatoes (Solanum tuberosum L.) to salinity in an arid environment and field performance of the seed tubers grown with fresh water in the following season. Agricultural Water Management 116:122-127. 
Levy, D., and Veilleux, R.E. 2007. Adaptation of potato to high temperatures and salinity. American Journal of Potato Research 84:487-506.

Lloyd, J.W., and Heathcote, J.A. 1985. Natural inorganic hydrochemistry in relation to groundwater. Oxford Press, Oxford, UK.

Merriam, J.L., and Keller, J. 1973. Irrigation system evaluation and improvement. Utah State University, Logan, Utah, USA.

Merriam, J.L., and Keller, J. 1978. Farm irrigation system evaluation: A guide for management. Utah State University, Logan, Utah.

Miller, D.E., and Martin, M.W. 1983. Effect of daily irrigation rate and soil texture on yield and quality of Russet Burbank potatoes. American Potato Journal 60:745-757.

Moore, A., Zglobicki, S., and Olsen, N. 2011. Manure management in potatoes: Salt accumulations in Idaho soils. p. 63-66. Idaho Potato Conference, Pocatello, Idaho. 19-20 January. Idaho State University, Pocatello, Idaho, USA.

Nagaz, K., Masmoudi, M.M., and Ben Mechlia, N. 2012. Yield response of drip irrigated onion under full and deficit irrigation with saline water in arid regions of Tunisia. ISRN Agronomy Vol. 212, Article ID 562315, 8 p. http://dx.doi. org/10.5402/2012/562315.

Oskoui, K.E., and Harvey, S.J. 1992. Predicting cone index from soil physical properties and organic matter content. ASAE Paper Nr 92-1056. p. 1-16. American Society of Agricultural Engineers (ASAE), St. Joseph, Michigan, USA.

Priya, K.L. 2013. A fuzzy logic approach for irrigation water quality assessment: A case study of Karunya Watershed, India. Journal of Hydrologic Engineering 2:1. doi:10.4172/23259647.1000104.

Redtflla, C.A., Davenport, J.R., Evans, R.G., Hattendorf, M.J., Alva, A.K., and Boydston, R.A. 2002. Relating potato yield and quality to field scale variability in soil characteristics. American Journal of Potato Research 79:317-323.

Roberto, A.R. Jr., Fontes, P.C.R., Neves, J.C.L., and Santos, N.T. 1999. Total soil electrical conductivity and critical soil $\mathrm{K}^{+}$to $\mathrm{Ca}^{2+}$ and $\mathrm{Mg}^{2+}$ ratio for potato crops. Scientia Agricola 56(4):993-997.

Samy, M.M. 2015. Effect of irrigation with saline water on the growth and production of some potato cultivars. Middle East Journal of Applied Sciences 5(4):1151-1163.

Sela, G. 2016. Irrigation water quality. Available at https://www. maximumyield.com/irrigation-water-quality/2/969 (accessed 13 February 2017).
Shamsad, S.Z.K.M., and Islam, M.S. 2005. Hydrochemical behavior of the water resource of Sathkhira Sadar of southwestern Bangladesh and its impact on environment. Bangladesh Journal of Water Resource Research 20:43-52.

Singh, S., Kumar, D., and Singh, B.P. 2004. Short note quantification of tuber shape in Indian potato cultivars. Potato Journal 31:205-207.

Suarez, D.L., Wood, J.D., and Lesch, S.M. 2008. Infiltration into cropped soils: Effect of rain and sodium adsorption ratioimpacted irrigation water. Journal of Environmental Quality 37:169-179.

Suliman, A.F., Ghoniem, E.Y., and Abdou, F.M. 1999. Some physical and mechanical properties of potato concerning the design of diggers and handling operations. p. 290-301. Proceeding of the seventh conference of Misr Society of Agricultural Engineering, Alexandria, Egypt. 27-28 October 1999. Misr Society of Agricultural Engineering, Cairo, Egypt.

Tabatabaeefar, A. 2002. Size and shape of potato tubers. Agrophysics 16:301-305.

Tanji, K.K. 1990. Agricultural salinity assessment and management. American Society of Civil Engineers (ASCE) Manuals and Reports on Engineering Practice Nr 71. American Society of Civil Engineers (ASCE), New York, USA.

Tanner, C.B., and Sinclair, T.R. 1983. Efficient water use in crop production: Research or re-search? p. 1-27. In Taylor, H.M., Jordan W.R., and Sinclair, T.R. (eds.) Limitations to efficient water use in crop production. American Society of Agronomy, Crop Science Society of America, Soil Science Society of America, Madison, Wisconsin, USA.

The World Factbook. 2016. Saudi Arabia Economy Profile 2016. Central Intelligence Agency (CIA), Washington, D.C., USA. Available at http://www.indexmundi.com/saudi_arabia/ economy_profile.html (accessed February 2017).

Van Hoorn, I.W., Katerji, N., Hamdy, A., and Mastrorilli, M. 2002. Effect of saline water on soil salinity and on water stress, growth, and yield of wheat and potatoes. In Katerji, N., Hamdy, A., van Hoorn, I.W., and Mastrorilli, M. (eds.) Mediterranean crop responses to water and soil salinity: eco-physiological and agronomic analyses. Options Méditerranéennes: Série B. Etudes et Recherches 36:17-40.

Yavuz, D., Kara, M., and Suher, S. 2012. Comparison of different irrigation methods in terms of water use and yield in potato farming. Journal of Selcuk University Natural and Applied Science 1(2):1-12. 